\title{
Interconnection between Nail Growth and Blood in Urine
}

\author{
Muhammad Imran Qadir, Sana Zainab* \\ Institute of Molecular Biology and Biotechnology, Bahauddin Zakariya University, Multan, Pakistan
}

*Corresponding Author: Sana Zainab, Institute of Molecular Biology and Biotechnology, Bahauddin Zakariya University, Multan, Pakistan

\begin{abstract}
The goal of this study was to Interconnect Nail Growth and Blood in Urine. Presence of blood in urine is outline as haematuria. Blood that you'll see in urine is outline as visible symptom and blood which cannot be seen and may solely be seen beneath magnifier is define as microscopic haematuria. Thanks to presence of blood cells in urine color of urine changes and turns to pink, red or chromatic black color. Nail is a cover and horn-like structure that cover our toes and fingers. Nails are like paws in various creatures. Fingernails Associate in nursing toenails is formed from associate degree extreme defensive super molecule noted as alpha-keratin. The research was held in Bahauddin Zakariya University, Multan, Pakistan. Total of 100 students participated in this research. We checked their blood level in urine by performing urine test. We make an excel sheet and write their blood level in urine in front of their name and then asked them about nail growth pattern and also write nail growth days with blood level in urine. The research was performed to interconnect the nail growth with blood level in urine. Male and female subjects with slow nail growth show the highest percentage in negative non hemolysis
\end{abstract}

Keywords: Nail growth, hematuria, hemolysis, non hemolysis.

\section{INTRODUCTION}

Presence of blood in urine is outline as haematuria. Blood that you'll see in urine is outline as visible symptom and blood which cannot be seen and may solely be seen beneath magnifier is define as microscopic haematuria. Thanks to presence of blood cells in urine color of urine changes and turns to pink, red or chromatic black color. Touch of blood will amendment the color of urine, in symptom kidneys or different components of tract let the blood cells to flow into urine. Several issues will cause this outpouring. This occurs once microorganism enters the body through the channel and multiplies in bladder. Negative effects are bladder contaminations however kidney diseases also are been accountable to cause fever or torment. Excretory organ stones also are shaped once some valuable stones may be transforming the insufficient and onerous stones. There are not any direct signs that indicate the presence of those stones except if they cause a blockage whereas passing. Minute dying and each gross are caused by bladder or excretory organ stones. Prostate organ is a component of duct that is gift beneath the gall bladder close of augments once the boys are at time of life. it's some extent that packs duct and block excrement flow. Similar signs are shown once prostate illness is caused. Unambiguous urinary exhausting is also a sign of wounding edge kidney, gall bladder or prostate malignancy (1).

Nail is a cover and horn-like structure that cover our toes and fingers. Nails are like paws in various creatures. Fingernails Associate in nursing toenails is formed from associate degree extreme defensive super molecule noted as alpha-keratin. This super molecule is additionally found among the hooves and horns of various creatures. The framework, in some cases noted because the grid advanced piece, keratogenous film and nails lattice. Below the nail there are many nerves that contain blood. Symptoms embrace these factors like persistent urge to urinate, pain and burning throughout excretion and extremely strong-smelling piddle. For some people, notably older adults, the only sign of unhealthiness may be microscopic blood among the piddle. to check the symptom, take piddle sample terribly\} very sterilized instrumentation so checked it with strip and anticipate one to minute so match the results of strip with the actual color pattern on the box and write. This super molecule is additionally found among the hooves and horns of various creatures. Under the nails there are many body fluids and blood vessels also present and their lattice produces cells that end up to be the nail plate. The dimension and thickness of the nail plate is controlled by the size the size of the nail, length 
of the whole nail as well as the thickness of the framework of nails. Whereas the tip of the nails itself looks if the nail plate is at any level, angled and hooked(The network will bear on creating cells as long as a result of it gets sustenance and stays terribly) very hard conditions. When the new nail plate cells are arises then they push older nail plate cells onward and set them on these lines extra seasoned cells finally end up compacted, level, and clear. This makes the vessels among the nail bed below noticeable, delivery a pair of pink. The target of gift study was to interconnect the nail growth with symptom (2).

The goal of this study was to Interconnect Nail Growth and Blood in Urine.

\section{MATERiAl AND MethodS}

\subsection{Project Designing}

The research was held in Bahauddin Zakariya University, Multan, Pakistan. Total of 100students participated in this research. We checked their blood level in urine by performing urine test. We asked them to take their urine sample in a sterilized plastic container and then checked their blood level with the help of urine testing strip. We took out strip from box and dip in urine and let it set for 2 or 3 seconds and then matched the corresponding color with the colour list given on the box. We make an excel sheet and write their blood level in urine in front of their name and then asked them about nail growth pattern and also write nail growth days with blood level in urine. The research was performed to interconnect the nail growth with blood level in urine (3-12).

\subsection{Statistical Analysis}

Percentage of all the data was done to analyze the data.

\section{Results}

Following table shows the percentage of hemolysis and non hemolysis in male students. Male student with slow nail growth shows the highest percentage in negative results, subjects with fast nail growth also show the high percentage in negative non haemolysis.

Table1: Interconnection between nail growth and haematuria in male subjects

\begin{tabular}{|l|l|l|l|l|l|l|l|}
\hline & & Haemolytic & & & \multicolumn{1}{|c|}{ Nonhaemolytic } & & \\
\hline Nail growth days & -ve & \multicolumn{1}{|c|}{$\mathbf{1 0 H}$} & $\mathbf{5 0 H}$ & $\mathbf{2 5 0 H}$ & $\mathbf{1 0 N}$ & $\mathbf{5 0 N}$ & $\mathbf{2 5 0 N}$ \\
\hline $1-5$ & $93 \%$ & $0 \%$ & $7 \%$ & $0 \%$ & $0 \%$ & $0 \%$ & $0 \%$ \\
\hline $6-10$ & $67 \%$ & $0 \%$ & $0 \%$ & $0 \%$ & $33 \%$ & $0 \%$ & $0 \%$ \\
\hline $11-15$ & $100 \%$ & $0 \%$ & $0 \%$ & $0 \%$ & $0 \%$ & $0 \%$ & $0 \%$ \\
\hline $16-20$ & $0 \%$ & $100 \%$ & $0 \%$ & $0 \%$ & $0 \%$ & $0 \%$ & $0 \%$ \\
\hline
\end{tabular}

Table 2 show the haemolytic and non-haemolytic results of female students. Female also show the similar results as that of males. Females with slow nail growth show the highest percentage in negative non haemolysis.

\begin{tabular}{|l|l|l|l|l|l|l|l|}
\hline & & Haemolytic & & & Nonhaemolytic & & \\
\hline Nail growth days & -ve & $\mathbf{1 0 H}$ & $\mathbf{5 0 H}$ & $\mathbf{2 5 0 H}$ & $\mathbf{1 0 N}$ & $\mathbf{5 0 N}$ & $\mathbf{2 5 0 N}$ \\
\hline $1-5$ & $84 \%$ & $8 \%$ & $0 \%$ & $8 \%$ & $0 \%$ & $0 \%$ & $0 \%$ \\
\hline $6-10$ & $88 \%$ & $9 \%$ & $3 \%$ & $0 \%$ & $0 \%$ & $0 \%$ & $0 \%$ \\
\hline $11-15$ & $100 \%$ & $0 \%$ & $0 \%$ & $0 \%$ & $0 \%$ & $0 \%$ & $0 \%$ \\
\hline $16-20$ & $80 \%$ & $0 \%$ & $0 \%$ & $20 \%$ & $0 \%$ & $0 \%$ & $0 \%$ \\
\hline
\end{tabular}

\section{DISCUSSION}

Nail growth has been linked with blood grouping in earlier studies and that study show the relation between nail growth and blood grouping. But the recent research interconnection of nail growth with haematuria has not linked earlier; it is a novel research which linked the blood in urine with pattern of nail growth.

\section{CONCLUSION}

Male and female subjects with slow nail growth show the highest percentage in negative non hemolysis. 


\section{REFERENCES}

[1] Kirby T, Baloa LA, Witt EK, inventors; RIC INVESTMENTS LLC, assignee. Systems and methods for controlling breathing rate. United States patent US 7,556,038. 2009 Jul 7.

[2] Stevens ED, Randall DJ. Changes in blood pressure, heart rate and breathing rate during moderate swimming activity in rainbow trout. Journal of Experimental Biology. 1967 Apr 1;46(2):307-15.

[3] Bernardi L, Spadacini G, Bellwon J, Hajric R, Roskamm H, Frey AW. Effect of breathing rate on oxygen saturation and exercise performance in chronic heart failure. The Lancet. 1998 May 2;351(9112):1308-11.

[4] Tarassenko L, Mason CL, inventors; Oxford University Innovation Ltd, assignee. Combining measurements from breathing rate sensors. United States patent US 7,318,808. 2008 Jan 15.

[5] Qadir MI, Javid A (2018) Awareness about Crohn's Disease in biotechnology students. GloAdv Res J Med Medical Sci, 7(3): 062-064.

[6] Qadir MI, Saleem A (2018) Awareness about ischemic heart disease in university biotechnology students. GloAdv Res J Med Medical Sci, 7(3): 059-061.

[7] Qadir MI, Ishfaq S (2018) Awareness about hypertension in biology students. Int J Mod Pharma Res, 7(2): 08-10.

[8] Qadir MI, Mehwish (2018) Awareness about psoriasis disease. Int J Mod Pharma Res, 7(2): 17-18.

[9] Qadir MI, Shahzad R (2018) Awareness about obesity in postgraduate students of biotechnology. Int J Mod Pharma Res, 7(2): 14-16.

[10] Qadir MI, Rizvi M (2018) Awareness about thalassemia in post graduate students. MOJ Lymphology \& Phlebology, 2(1): 14-16.

[11] Qadir MI, Ghalia BA (2018) Awareness survey about colorectal cancer in students of M. Phil Biotechnology at Bahauddin Zakariya University, Multan, Pakistan. Nov Appro in Can Study, 1(3): NACS.000514.2018.

[12] Qadir MI, Saba G (2018) Awareness about intestinal cancer in university student. Nov Appro in Can Study, 1(3): NACS.000515.2018.

Citation: Muhammad Imran Qadir, Sana Zainab, "Interconnection between Nail Growth and Blood in Urine" International Journal of Research Studies In Biosciences (Ijrsb), Vol. 7, no. 7, pp. 20-22, 2019. http://Dx.Doi.org/10.20431/2349-0365.0707004

Copyright: (C) 2019 Authors. This is an open-access article distributed under the terms of the Creative Commons Attribution License, which permits unrestricted use, distribution, and reproduction in any medium, provided the original author and source are credited. 